\title{
Research on Construction of Drug Safety Management System for Pregnant Women based on Rainbow Model
}

\author{
Ming Cai ${ }^{a}$, Huimin $\mathrm{Yu}^{\mathrm{b}}$, Shuangyan $\mathrm{Yu}{ }^{\mathrm{c},}$ * \\ Jiangxi University of Traditional Chinese Medicine, Nanchang, Jiangxi, China \\ a1327858049@qq.com, b2933788893@qq.com, c, * 444639882@qq.com
}

\begin{abstract}
The use of drugs in pregnant women, a special group, not only affects the health of pregnant women themselves, but also may affect the fetus to some extent. In view of this, this paper, taking the rainbow model as the theoretical framework, from the macro, meso and micro four levels, and support elements in system integration, professional integration, organization integration, clinical integration, function integration, and integration of specification six dimensions to build integrated pregnancy women's medication security management system, to prevent the foreseeable damage, It has important and far-reaching guiding significance to further improve the medication safety of pregnant women.
\end{abstract}

Keywords: Rainbow Model; Pregnant Women; Drug Safety; Integrated Management System.

\section{The Necessity of Constructing Medication Safety Management System for Pregnant Women}

\subsection{Main Physiological Changes and Pharmacokinetic Characteristics of Pregnant Women}

During pregnancy, in order to adapt to and meet the needs of fetal growth and development in utero, a series of physiological changes will occur in the mother, which will affect both pharmacokinetics and pharmacokinetics. (See Table 1)

Table 1. Main physiological changes and pharmacokinetic characteristics during pregnancy

\begin{tabular}{|c|c|c|c|}
\hline The name & Physiological changes & Pharmacokinetic effects & $\begin{array}{c}\text { Blood drug } \\
\text { concentration }\end{array}$ \\
\hline absorption & $\begin{array}{c}\text { Increased progesterone secretion can cause } \\
\text { decreased tension of gastrointestinal smooth } \\
\text { muscle, relaxation of cardiac sphincter, } \\
\text { decreased secretion of digestive fluid, prolonged } \\
\text { gastric emptytime, decreased intestinal } \\
\text { peristalsis and so on }\end{array}$ & $\begin{array}{c}\text { Reduced or increased } \\
\text { absorption/bioavailability }\end{array}$ & $\begin{array}{c}\text { To decrease } \\
\text { or increase. }\end{array}$ \\
\hline \multirow{5}{*}{ distribution } & $\begin{array}{c}\text { Gestational blood volume begins to increase at } \\
6-8 \text { weeks of gestation and peaks at 32-34 } \\
\text { weeks of gestation, with an approximately 35- } \\
40 \% \text { increase in blood volume compared to pre- } \\
\text { gestation, and remains constant until delivery. }\end{array}$ & $\begin{array}{c}\text { This is represented by an } \\
\text { increase in the volume of } \\
\text { distribution }\end{array}$ & To reduce \\
\hline metabolic & $\begin{array}{c}\text { The activity of glucuronic acid transferase } \\
\text { decreased, the function of liver enzyme system } \\
\text { changed, so that the liver biotransformation } \\
\text { function decreased, easy to produce cumulative } \\
\text { poisoning. }\end{array}$ & $\begin{array}{c}\text { Bioconversion increases or } \\
\text { decreases }\end{array}$ & $\begin{array}{c}\text { To decrease } \\
\text { or increase. }\end{array}$ \\
\hline \multirow{5}{*}{ discharge } & $\begin{array}{c}\text { Glomerular filtration rate increased by about } \\
50 \% \text { and renal plasma flow increased by about } \\
75 \% \text {. Urine excretion of protein metabolites } \\
\text { urea, uric acid, creatine and creatinine increases. }\end{array}$ & Discharge increase & To reduce \\
\hline
\end{tabular}




\subsection{Fetal Pharmacokinetic Characteristics}

According to the size of the gestational age and the damage properties when the medication during pregnancy, can be found that fetal organs and functions in the development stage, the placenta can not effectively protect the fetus from drugs, most drugs can be through the placenta into the fetal body, and there are quite a number of drugs after metabolism and formation of harmful substances, and embryonic death or deformity, therefore, The pharmacokinetic characteristics of the fetus also require close attention. (See Table 2)

Table 2. Pharmacokinetic characteristics of fetuses

\begin{tabular}{|c|c|}
\hline The name & Pharmacokinetic characteristics of fetuses \\
\hline absorption & Most drugs are transported directly to the fetus across the placental barrier \\
\hline distribution & $\begin{array}{c}\text { Fetal blood brain barrier development is not perfect, drugs easily enter the central } \\
\text { nervous system. }\end{array}$ \\
\hline metabolic & $\begin{array}{c}\text { Fetal liver is the main organ of drug metabolism, placenta and adrenal gland are } \\
\text { also involved in the metabolism of some drugs }\end{array}$ \\
\hline discharge & $\begin{array}{c}\text { After } 11 \text { to } 14 \text { weeks of gestation, fetal kidneys have excretory function, but their } \\
\text { function is very weak and significantly lower than that of adults. }\end{array}$ \\
\hline
\end{tabular}

\subsection{Attention has been Paid to Drug Use during Pregnancy}

According to statistics, pregnant women during pregnancy had taken at least one drug accounted for $90 \%$, taking at least 10 people accounted for $4 \%$, the average 8 kinds of drug used, and the doctor prescribed drugs accounted for only $20 \%$ of women during pregnancy drug use is widespread, informed or uninformed, active or passive using drugs, therefore, There are certain risks associated with safe medication during pregnancy.

\section{Research Methods and Analysis Framework}

Rainbow model has been widely used in the research of health management system integration strategy because it can objectively and comprehensively reflect the core elements and key characteristics of system integration. Therefore, by summarizing relevant policy documents and literature and taking rainbow model as a theoretical framework, this paper constructed an integrated drug safety management system for pregnant women.(See table 3)

Table 3. The meanings of different levels in the rainbow model

\begin{tabular}{|c|c|c|}
\hline Level & Dimension & Concepts and Meanings \\
\hline macro & System integration & $\begin{array}{l}\text { From the institutional level to the whole pregnancy Integration of } \\
\text { structure, process and technology of medication safety services }\end{array}$ \\
\hline \multirow[t]{2}{*}{ medium } & $\begin{array}{c}\text { Organization } \\
\text { integration }\end{array}$ & Different types and levels of health care work together \\
\hline & $\begin{array}{r}\text { Professional } \\
\text { integration }\end{array}$ & Medical staff of different specialties cooperate with each other \\
\hline micro & Clinical integration & $\begin{array}{l}\text { According to the actual situation of pregnant women, personalized } \\
\text { medication guidance or program is provided for pregnant women }\end{array}$ \\
\hline \multirow[t]{2}{*}{$\begin{array}{l}\text { Support } \\
\text { elements }\end{array}$} & $\begin{array}{l}\text { Functional } \\
\text { integration }\end{array}$ & $\begin{array}{l}\text { Use modern scientific information technology to promote and } \\
\text { guarantee the development of drug use safety of pregnant women }\end{array}$ \\
\hline & $\begin{array}{c}\text { Normative } \\
\text { integration }\end{array}$ & $\begin{array}{c}\text { The standards and interdependent climate around drug safety in } \\
\text { pregnancy }\end{array}$ \\
\hline
\end{tabular}




\section{Construct Drug Safety Management System for Pregnant Women}

\subsection{System Integration}

From the perspective of system integration, improving the corresponding policy guarantee system and supporting facilities is a strong guarantee and prerequisite for the construction of drug safety management system for pregnant women. First of all, work tasks, processes, institutional norms and responsibilities of relevant personnel should be clarified for each institution in the system. Secondly, it is necessary to clarify the good service groups, service content, time period and the rights and obligations of the supply and demand parties and other relevant matters; Finally, strong supporting facilities should be established.

\subsection{Organizational Integration}

From the perspective of vertical collaboration and integration, medical institutions of different types and levels are encouraged to cooperate and establish different forms of drug use consortions by sorting out and referring to the main cooperation forms of medical consortions. The main forms include urban medical drug use group, county medical drug use community, cross-regional maternal and child specialty alliance, telemedicine drug use cooperation platform, urban and rural counterpart assistance, trusteeship, technical cooperation, etc.

\subsection{Professional Integration}

From the perspective of horizontal collaboration and integration, medical staff of different disciplines and specialties are encouraged to participate in drug use services during pregnancy, so as to provide safe, convenient and reasonable drug use services for pregnant women. There are also many scholars and experts in Our country to carry out research on this aspect.

\subsection{Clinical Integration}

From the perspective of clinical integration, personalized medication safety services in pregnancy should be carried out. Each region can design a medication management system with reasonable types, rich contents and distinctive characteristics according to its own economic development, scientific development level and medical resources. Under this management system, different ways, dosage and duration of medication can be adopted according to the actual situation of pregnant women or reasonable and safe medication can be adopted according to the corresponding basic principles of medication during pregnancy.

\subsection{Function Integration}

From the perspective of functional integration, the use of advanced network, communication, computer and digital technology to realize intelligent collection, conversion, storage, transmission and post-processing of medical medication information, as well as the digital operation of various medical business processes, to improve the safety and efficiency of medication for pregnant women. In particular, it plays an important role in medication management of pregnant women in grass-root, remote and underdeveloped areas.

\subsection{Specification Integration}

From the perspective of normative integration, build corresponding around pregnancy women drug safety standards and the atmosphere of mutual dependence, strengthen the public health administrative department under the system of management, establish assessment evaluation and supervision and inspection mechanism, perfect the corresponding incentive mechanism, improve the level of medical staff of the business and the sense of responsibility, etc., and depend on each other to create better medical environment, Thus better guarantee pregnant women reasonable and safe drug use. 


\section{Conclusion}

Medication during pregnancy because of its relationship to the maternal and fetal health, growth and development and the attention of people, but the safe drug use there are many problems during pregnancy, pregnancy women drug safety management system because of its integrated measures in detail, institutions function classification clear, reasonable resources allocation as a whole, the advantages of the integration mode innovation, It can effectively promote the safe and reasonable drug use of pregnant women and improve their drug use experience during pregnancy.

\section{References}

[1] liu q y. guidance of medication for common diseases during pregnancy [J]. Chinese rural medicine, 2019, $26(3): 77-78$.

[2] li bijun. Precautions for medication in pregnant women [J]. Chinese journal of medical innovation, 2014, $11(20): 123-125$.

[3] Yue Yang, $\mathrm{Xu} \mathrm{Fu}$, Jia Cunde. Analysis of medication consultation and establishment of safe medication rules in pregnant women [J]. China pharmaceutical industry,2020,29(8):83-85. 